21. Mann, J. and Barnett, H., Lethal tiger shark (Galeocerdo cuvier) attack on bottlenose dolphin (Tursiops sp.) calf: defense and reactions by the mother. Mar. Mamm. Sci., 1999, 15(2), 568-575.

22. Altmann, J., Observational study of behavior: sampling methods. Behaviour, 1974, 49(3), 227-266.

23. Mead, J. G. and Potter, C. W., Natural history of bottlenose dolphins along the central Atlantic coast of the United States. In The Bottlenose Dolphin (eds Leatherwood, S. and Reeves, R. R.), Academic Press, New York, USA, 1990, pp. 165-195.

24. Cockcroft, V. G. and Sauer, W., Observed and inferred epimeletic (nurturant) behaviour in bottlenose dolphins. Aquat. Mamm., 1990, 16(1), 31-32.

25. Cremer, M. J., Hardt, F. A. S. and Júnior, A. J. T., Evidence of epimeletic behavior involving a Pontoporia blainvillei calf (Cetacea, Pontoporiidae). Biotemas, 2006, 19(2), 83-86.

26. Connor, R. C. and Norris, K. S., Are dolphins reciprocal altruists?. Am. Nat.., 1982, 119(3), 358-374.

27. Scott, E. M., Mann, J., Watson-Capps, J. J., Sargeant, B. L. and Connor, R. C., Aggression in bottlenose dolphins: evidence for sexual coercion, male-male competition, and female tolerance through analysis of tooth-rake marks and behaviour. Behaviour, 2005, 142(1), 21-44.

28. Robinson, K. P., Agonistic intraspecific behavior in free-ranging bottlenose dolphins: Calf-directed aggression and infanticidal tendencies by adult males. Mar. Mamm. Sci., 2014, 30(1), 381-388.

29. López, B. D., López, A., Methion, S. and Covelo, P., Infanticide attacks and associated epimeletic behaviour in free-ranging common bottlenose dolphins (Tursiops truncatus). J. Mar. Biol. Assoc. $U K, 2018,98(5), 1159-1167$.

30. Ritter, F., Behavioral responses of rough-toothed dolphins to a dead newborn calf. Mar. Mamm. Sci., 2007, 23(2), 429-433.

31. Park, K. J., Sohn, H., An, Y. R., Moon, D. Y., Choi, S. G. and An, D. H., An unusual case of care-giving behavior in wild long-beaked common dolphins (Delphinus capensis) in the East Sea. Mar. Mamm. Sci., 2013, 29(4), 508-514.

32. Brodie, P. F., Duration of lactation in Cetacea: an indicator of required learning? Am. Midl. Nat., 1969, 82(1), 312-314.

33. Lodi, L., Epimeletic behavior of free-ranging rough-toothed dolphins, Steno bredanensis, from Brazil. Mar. Mamm. Sci., 1992, 8(3), 284-287.

34. Mann, J., Connor, R. C., Barre, L. M. and Heithaus, M. R., Female reproductive success in bottlenose dolphins (Tursiops sp.): life history, habitat, provisioning, and group-size effects. Behav. Ecol., 2000, 11(2), 210-219

35. Reggente, M. A., Alves, F., Nicolau, C., Freitas, L., Cagnazzi, D., Baird, R. W. and Galli, P., Nurturant behavior toward dead conspecifics in free-ranging mammals: new records for odontocetes and a general review. J. Mammal., 2016, 97(5), 1428-1434.

36. Quintana-Rizzo, E. and Wells, R. S., Behavior of an adult female bottlenose dolphin (Tursiops truncatus) toward an unrelated dead calf. Aquat. Mamm., 2016, 42(2), 198-202.

37. Pilleri, G., Epimeletic behaviour in Cetacea: intelligent or instinctive. Invest. Cetacea, 1984, 16, 30-48.

38. Allen, C. and Hauser, M. D., Concept attribution in nonhuman animals: theoretical and methodological problems in ascribing complex mental processes. Philos. Sci., 1991, 58(2), 221-240.

39. Sugiyama, Y., Kurita, H., Matsui, T., Kimoto, S. and Shimomura, T., Carrying of dead infants by Japanese macaque (Macaca fuscata) mothers. Anthropol. Sci., 2009, 117(2), 113-119.

40. Hrdy, S. B., Mother Nature: A History of Mothers, Infants, and Natural Selection, Chatto \& Windus, London, UK, 1999.

41. Whitehead, H. and Mann, J., Female reproductive strategies of cetaceans. In Cetacean Societies: Field Studies of Dolphins and Whales (eds Mann, J. et al.), University of Chicago Press, Chicago, USA, 2000, pp. 219-246.

42. Mann, J. and Smuts, B. B., Natal attraction: allomaternal care and mother-infant separations in wild bottlenose dolphins. Anim. Behav., 1998, 55(5), 1097-1113.
43. Harzen, S. and dos Santos, M. E., Three encounters with wild bottlenose dolphins (Tursiops truncatus) carrying dead calves. Aquat. Mamm., 1992, 18(2), 49-55.

44. Kuczaj, S. A., Frick, E. E., Jones, B. L., Lea, J. S., Beecham, D. and Schnöller, F., Underwater observations of dolphin reactions to a distressed conspecific. Learn. Behav., 2015, 43(3), 289-300.

45. Fertl, D. and Schiro, A., Carrying of dead calves by free-ranging Texas bottlenose dolphins (Tursiops truncatus). Aquat. Mamm., 1994, 20, 53-56

46. Kilborn, S. S., Object carrying in a captive beluga whale (Delphinapterus leucas) as possible surrogate behavior. Mar. Mamm. Sci., 1994, 10(4), 496-501.

47. Livingstone, M. S., Maternal attachment to a stuffed toy by a macaque. J. Primatol., 2015, 4(2), 1-2.

48. King, B. J., How Animals Grieve, University of Chicago Press, Chicago, USA, 2013.

ACKNOWLEDGEMENTS. The observations recorded in this study are a part of the 'Sindhudurg Cetacean Project', funded by the UNDPGoI-GEF Sindhudurg Project, 'Mainstreaming Coastal and Marine Biodiversity Conservation into Production Sectors in Sindhudurg Coast in Maharashtra'. Necropsies were conducted with permission from the Maharashtra State Forest Department (file no: PSF-2013/MM/PA-4). We thank the Maharashtra State Forest Department and the Mangrove Cell for their support. We also thank Rajendra Mumbarkar, Mahesh Tandel and the entire fishing community of Sindhudurg for their help and cooperation throughout the study.

Received 27 February 2019; revised accepted 12 June 2020

doi: $10.18520 / \mathrm{cs} / \mathrm{v} 119 / \mathrm{i} / 1363-1367$

\section{Occurrence of a cyprinid fish (Leuciscinae) from latest Neogene (?Pliocene) sediments of Chotanagpur plateau, eastern India}

\author{
Manoshi Hazra ${ }^{1,2}$, Taposhi Hazra ${ }^{1}$, Subir Bera ${ }^{3}$ \\ and Mahasin Ali Khan ${ }^{1, *}$
}

${ }^{1}$ Department of Botany, Sidho-Kanho-Birsha University, Ranchi Road, Purulia 723 104, India

${ }^{2}$ Presidency University, 86/1, College Street, Calcutta University Road, Kolkata 700 073, India

${ }^{3}$ Centre of Advanced Study, Department of Botany,

University of Calcutta, 35, B.C. Road, Kolkata 700 019, India

A compressed fossil fish bearing close resemblance to sub-family Leuciscinae (family: Cyprinidae) is reported from latest Neogene (?Pliocene) sediments of Chotanagpur plateau, eastern India. The recovered fossil fish contains exceptionally well-preserved skeleton. It

*For correspondence. (e-mail: khan.mahasinali@gmail.com) 
is characterized by compressed belly, medium-sized head, well-preserved skull, ten caudal vertebrae, moderately long vertebral spines, cycloid scales, and wellpreserved dorsal, pectoral, pelvic, anal and caudal fins. The fossil material and associated angiospermic flora indicate the existence of Leuciscinae and freshwater lacustrine environment (with intermittent fluvial incursions during flood events) in the Chotanagpur plateau during the depositional period.

Keywords: Angiospermic flora, fossil fish, freshwater, lacustrine environment.

THE Chotanagpur Plateau in the eastern part of the Indian peninsula, covers an area of about $75,000 \mathrm{sq}$. $\mathrm{km}$ with an average elevation of 600-800 m amsl (ref. 1). Geologically, it consists of Dharwar rocks, Archaean granites (Singhbhum granite batholith) with some sedimentary and metamorphic deposits of iron ore. This plateau is blessed with rich natural resources, fertile soils and forests rich in floristic composition. The Chotanagpur plateau was uplifted during the Cenozoic, which was marked by numerous geomorphic features like waterfalls, rapids, river terraces, etc. ${ }^{2}$.

The study area, Mahuadanr valley, Chotanagpur plateau Jharkhand, represents latest Neogene sedimentary deposits of fluvial origin ${ }^{3,4}$. The sediments of the area are mainly exposed along the banks of Birha River and its tributaries, extending about $2.6 \mathrm{~km}$ in length and $1.5 \mathrm{~km}$ wide. The Precambrian Chotanagpur gneiss forms the basement for the deposition of these sediments. The stratigraphic sequence includes lithologies like pyroclastic sediments, conglomerates, sandstones and shales (Figure 1). The studied sedimentary section covers a length of about $50 \mathrm{~m}$ and reaches a maximum thickness of $5 \mathrm{~m}$. The lithology comprises of mostly shale and sandstone (Figure 2). The type of shale varies from arenaceous to clayey. The sandstone occurs interbedded between the shale layers. Mudballs having round to elliptical shape also occur embedded in this sandstone unit. The upper fossiliferous unit of $0.5 \mathrm{~m}$ contains abundant fossil biota, including angiosperm leaf impressions and compressions, fruit remains, flowers, wood and fish remains. Earlier workers have assigned a latest Neogene to this sedimentary section ${ }^{3-5}$. The sediments are usually regarded to be of Pliocene age $e^{4-6}$, but till date there is no definitive evidence for the same. Prior to this report, the sedimentary section was already studied for its vertebrate faunal content of fishes and birds ${ }^{3}$. Puri and Mishra ${ }^{3}$ reported fossil fish remains having affinity with modern fishes of the Clupidae family from the latest Neogene sediments of Latehar district, Jharkhand. Here we describe the remains of a well-preserved compressed fish closely resembling the modern fishes of sub-family Leuciscinae from the same locality. This is an authentic record of Leuciscinae fish from Cenozoic sediments of India. Modern Leucisci- nae belong to one of the main branches of cyprinids and are further composed of secondary branches with clade names Barilini, Rasborini, Cultrini, Acheilognathini, Leuciscini and Phoxinini. The leuciscine has a characteristic mechanism of swimming with its head lifted above the water and its mouth opened to prey upon aquatic and terrestrial insects.

During fieldwork (May 2019), we collected a wellpreserved fossil fish specimen with complete skeleton from latest Neogene sediments (?Pliocene) of Mahuadanr valley $\left(23.40^{\circ} \mathrm{N}, 84.11^{\circ} \mathrm{E}\right.$; altitude $353 \mathrm{~m}$ amsl) (Figure $1)^{7}$. The fossil fish was carefully recovered using chisel and shovel. After cleaning, macroscopic images of the specimen were photographed using a digital camera (Canon Power Shot A720IS) (Figure 3). The underlying and overlying horizons of the same formation also contained numerous fossil angiospermic leaf remains. The fossil specimen (SKBUH/PPL/JH/FH1) is kept at the Herbarium and Museum, Department of Botany, SidhoKanho-Birsha University, Purulia, India (SKBUH). A thorough morpho-anatomical description of the fossil specimen is presented below.

Body moderately deep, compressed belly, length $23 \mathrm{~cm}$ and width $6.5 \mathrm{~cm}$; head moderate in size, skull bones well-preserved, $2.5 \mathrm{~cm}$; mouth terminal and mouth gape oblique; parietals seemingly visible, but the structure deformed; the abdominal vertebra disarticulated and displaced anteriorly, nearly about 10 caudal vertebrae wellpreserved and articulated in a straight vertebral column, the vertebral column almost elevated anteriorly; the vertebral spines moderately long, relatively slender and almost straight; scales cycloid; dorsal, pectoral, pelvic, anal and caudal fins well-preserved; dorsal fin situated closer to the base of the caudal fin and posterior to pelvic fin that arises near the middle part of the body on dorsal side, approximately 10 fins are visible; pectoral fin preserved, situated posterior to skull, short, pectoral fin rays seemingly visible; pelvic fin situated near the ventral body margin, nearly eight fin rays that are segmented distally; anal fin base long, situated posterior to ventral margin of body with distinct fin rays; caudal fin moderately large, deeply forked with the upper and lower lobes of equal length with more than thirty fin rays, segmented from middle parts, caudal peduncle not constricted.

The above-mentioned morpho-anatomical features of fish specimen suggest its closest resemblance to those of the modern fish members of Leuciscinae. On the basis of morphological description and comparison with data on the morphology of recent Indian fishes, this fossil specimen shows resemblance to the modern genera Abramis Cuvier, Blicca Heckel, Chondrostoma Agassiz and Leuciscus Cuvier belonging to the sub-family of freshwater fishes, Leuciscinae. However, we need more samples and further morphometric analyses to confirm the exact generic affinity. Imoto et al. ${ }^{8}$ suggested that an ancestral species of Leuciscinae originated in Late Cretaceous of 


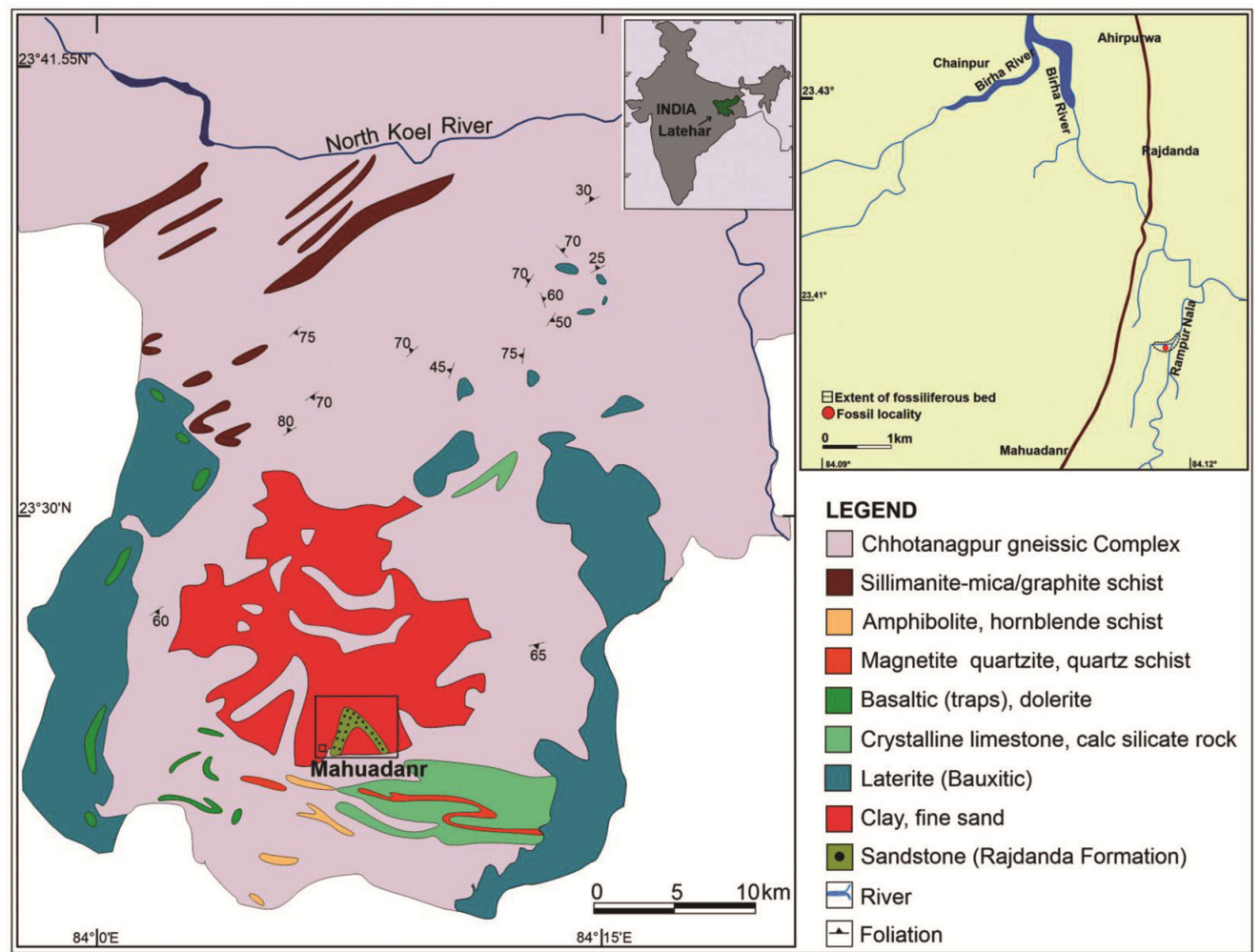

Figure 1. Geological map (modified District Resource Map of Palamau and Garhwa, Jharkhand published under the direction of Director General, Geological Survey of India) and fossil locality map of the area near Mahuadanr, Latehar district, Jharkhand (modified from Toposheet No. F45A3, Survey of India).

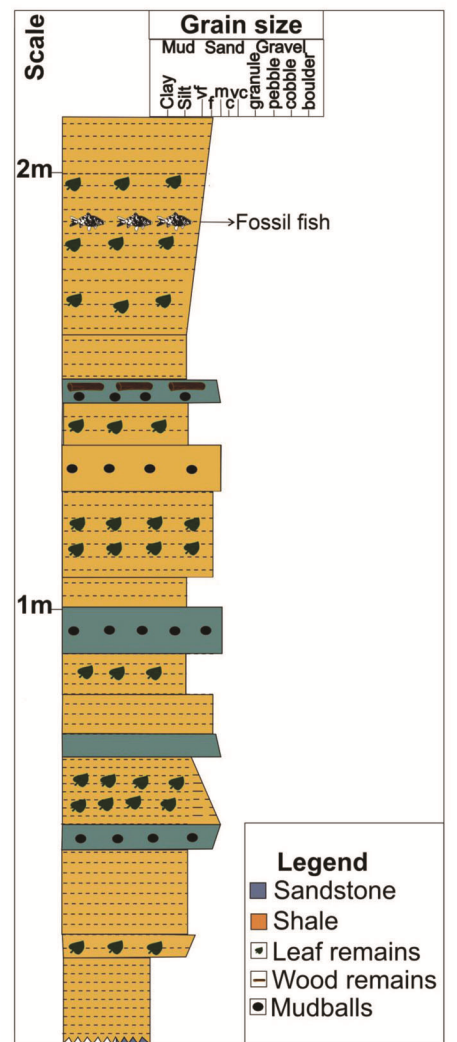

Figure 2. Composite graphic litholog of exposed sedimentary section using software SedLog 3.0.

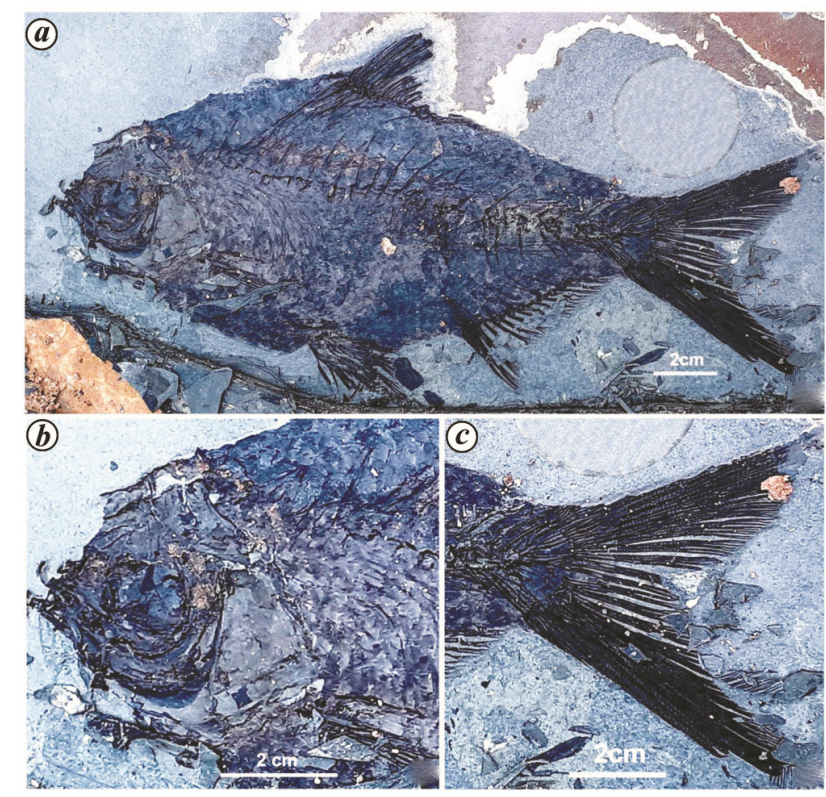

Figure 3. $\boldsymbol{a}$, Recovered fossil fish specimen (SKBUH/PPL/JH/I1). $\boldsymbol{b}$, Enlarged view of skull of fossil specimen. $c$, Enlarged view of tail segment of fossil specimen.

Europe based on phylogenetic analysis. However, the oldest fossil record of cyprinid identified as 'Blicca' croydonensis and having affinity with Leuciscinae fishes comes from early Eocene Woolwich Beds of the London 
Basin ${ }^{9}$. However, the identification is still questionable. An ancestral species of Leuciscinae originated in Late Cretaceous $(70.7 \mathrm{Mya})^{8}$. Leuciscinae were reported from Oligocene of Europe ${ }^{10,11}$. It has been recorded from Miocene of Shanwang Formation, Shanwang, Linqu city, Shandong Province, China ${ }^{12}$; Turkey ${ }^{13}$ and Germany ${ }^{14}$. Leuciscinae has also been reported from Pliocene of China $^{15}$. However, there are meagre records of cyprinid fossils from India. The fossil cyprinid fish scale comes from the lower Palaeogene (Palaeocene?) sediments of the Deccan intertrappean beds, Central India ${ }^{16}$. Till date there is no record of body fossil fish Leuciscini from India. However, fossil fish evidences of other families have been reported from Eocene sediments of Khuiala Formation of the Jaisalmer Basin, Vastan lignite mine, Panandhro lignite mine, western India ${ }^{17-19}$ and freshwater Siwalik deposits (Plio-Pleistocene) of north western India $^{20,21}$. Marine fishes (Decapterus (?) mizoramiensis, Pentaprion sahnii and Bothus (?) bhubanicus) were recorded from Miocene sediments of Surma Group, Mizoram, North East India ${ }^{22}$. The fish specimen described here is morphologically different from the aforementioned fossil fishes from India, and shows closest resemblance to the modern fish members of Leuciscinae.

Leuciscinae fishes being intolerant to salt water are mainly restricted to freshwater ${ }^{9,23}$. So, the present evidence of fossil cyprinid may reflect existence of freshwater lacustrine environment. The fish specimen was found associated with prolific and diversified tropical angiospermic plant remains. Plant remains are represented by abundant dicot and monocot leaves, fruit and wood remains. In addition, evidence of abundant aquatic grasses from the fossil locality also suggests a freshwater environment of deposition. So, the presence of tropical terrestrial plants and freshwater vertebrate remains suggests mixing of fauna and flora in fully shallow freshwater conditions. More in-depth anatomical study is necessary for identification of the specimen up to genus as well as species level. Further, geochemical analysis of body parts of the fish remains is yet to be done. We hope that this study provides a launching pad for further detailed studies of the newly collected materials which will provide a clear picture of their morphology, phylogeny and palaeobiogeographical implications in a nottoo-distant future.

1. Karan, P. P., Economic regions of Chota Nagpur, Bihar, India. Econ. Geogr., 1953, 29, 216-250.

2. Kailasam, L. N., Plateau uplift in peninsular India. Tectonophysics, 1979, 61, 243-269.

3. Puri, S. N. and Mishra, V. P., On the find of Upper Tertiary plant, fish and bird fossils near Rajdanda, Palamau district, Bihar. Rec. Geol. Surv. India, 1982, 112, 55-58.

4. Hazra, T. et al., Latest Neogene monsoon of the Chotanagpur Plateau, eastern India, as revealed by fossil leaf architectural signatures. Palaeogeogr., Palaeoclimatol., Palaeoecol., 2020; https://doi.org/10.1016/j.palaeo.2020.109641
5. Guleria, J. S., Neogene vegetation of peninsular India. Palaeobotanist, 1992, 40, 285-311.

6. District Resource Map of Palamau and Garhwa, Jharkhand published under the direction of Director General, Geological Survey of India, 2002.

7. Toposheet No. F45A3, Surveyor General of India, Survey of India, Dehradun, Government of India copyright, 2009.

8. Imoto, J. M. et al., Phylogeny and biogeography of highly diverged freshwater fish species (Leuciscinae, Cyprinidae, Teleostei) inferred from mitochondrial genome analysis. Gene, 2013, 514, $112-124$.

9. Cavender, T. M., The fossil record of the Cyprinidae. In Cyprinid Fishes, Springer, Dordrecht, the Netherlands, 1991, pp. 34-54.

10. Gaudant, J., New Research on Cyprinidae (teleost fish) Oligocenes of Limagnes. Geobios, 1984, 17, 659-666.

11. Sytchevskaya, E. K., Paleogene freshwater fish fauna of the USSR and Mongolia. Trudy Paleontol. Inst. Akod. Nauk. SSSR, 1986, 29, 1-157 (in Russian).

12. Tchang, T. L., Notes on a fossil fish from Shanxi. Bull. Geol. Soc. China, 1933, 12, 467-468.

13. Paicheler, J. C., Broin. F. deo Gaudant, G., Mourer-Chauvire, C., Rage. J. C. and Vergnaud-Grazzini. C., Le Bassin Lacustre Mioctme de Bes-Konak (AnatolieTurquie): Geologie et introduction a la paleontologie des vertebres. Geobios (Lyon), 1978, 11, 43-65.

14. Gaudant, J., Mise au point sur l'ichthyofaune miocene d'Öhningen (Baden, Allemagne). C.R. Hebd. Seanc. Acad. Sci. Paris, 1980, 291D, 1033-1036.

15. Liu, H. T. and Su, T., Pliocene fishes from the Yushe basin, Shansi. J. Vertebr. Paleontol., 1962, 6, 20.

16. Hora, S. L., On fossil fish scales from the Intertrappean beds at Deothan and Kheri, Central Provinces, Rec. Geol. Surv. India, 1938, 73, 267-294.

17. Kumar, K., Rana, R. S. and Singh, H., Fishes of the Khuiala Formation (Early Eocene) of the Jaisalmer Basin, Western Rajasthan, India. Curr. Sci., 2007, 93, 553-559.

18. Bajpai, S. and Kapur, V. V., Oldest known gobiids from Vastan Lignite Mine (early Eocene), District Surat, Gujarat. Curr. Sci., 2004, 87, 433-435.

19. Bajpai, S. and Thewissen, J. G. M., Vertebrate fauna from Panandhro lignite field (Lower Eocene), District Kachch,, western India. Curr. Sci., 2002, 82, 507-509.

20. Sahni, A. and Khare, S. K., A middle Siwalik fish fauna from Ladhyani (Haritalyangar), Himachal Pradesh. Biol. Mem., 1977, 2, $187-221$.

21. Kundal, S. N. and Prasad, G. V. R., Late Pliocene-Early Pleistocene microvertebrates from the Upper Siwalik Subgroup of Jammu, Jammu and Kashmir, India. Earth Sci. India, 2011, 4, $143-158$.

22. Tiwari, R. P. and Bannikov, A. F., Early Miocene marine fishes from the Surma Group, Mizoram India. Bull. Civic. Mus. Nat. Hist. Verona Geol. Paleontol. Preist., 2001, 25, 11-26.

23. Sousa-Santos, C., Jesus, T. F., Fernandes, C., Robalo, J. I. and Coelho, M. M., Fish diversification at the pace of geomorphological changes: evolutionary history of western Iberian Leuciscinae (Teleostei: Leuciscidae) inferred from multilocus sequence data. Mol. Phylogenet. Evol., 2019, 133, 263-285.

ACKNOWLEDGEMENTS. M.H., T.H. and M.A.K. thank the Department of Botany, Sidho-Kanho-Birsha University, Purulia for providing infrastructural facilities for this work. S.B. thanks the Centre of Advanced Study (Phase-VII), Department of Botany, University of Calcutta, Kolkata for providing the necessary facilities for this study.

Received 5 April 2020; revised accepted 12 August 2020

doi: $10.18520 / \mathrm{cs} / \mathrm{v} 119 / \mathrm{i} 8 / 1367-1370$ 